\title{
Early hypophysectomy of sheep fetuses: effects on growth, placental steroidogenesis and prostaglandin production
}

\author{
J. M. Deayton, I. R. Young and G. D. Thorburn \\ Department of Physiology, Monash University, Clayton 3168, Victoria, Australia
}

\begin{abstract}
The factors involved in the control of steroid secretion from the ovine placenta and in fetal growth are as yet unclear. We hypothesized that factors derived from the fetal pituitary may play a role in the production and release of placental steroids and in growth of the fetus, and have investigated the effects of fetal hypophysectomy performed between day 70 and day 79 of gestation (term $=147$ days) on systemic concentrations of hormones derived from the placenta, and on fetal growth. Maternal peripheral progesterone, placental lactogen and uterine vein progesterone increased significantly from day 90 in all ewes. Peripheral concentrations of prostaglandin $\mathrm{E}_{2}$ and peripheral and uterine vein oestrone sulfate increased significantly in the control group but not in the fetal hypophysectomy group. Uterine vein prostaglandin $E_{2}$ increased significantly after day 95 in the control group and after day 105 in the fetal hypophysectomy group. Early fetal hypophysectomy caused marked growth retardation. The weights of the brain, kidneys and liver of hypophysectomized fetuses were the same as those of controls suggesting that their growth is not under pituitary control. In contrast, the weights of heart and lungs were reduced in proportion to body weight, suggesting that heart, lung and carcass growth were under pituitary control. Our data indicate that the fetal pituitary influences the control of placental steroid and prostaglandin $E_{2}$ biosynthesis after day 90 of gestation in sheep, but that output of other hormones such as placental lactogen is independent of pituitary control, and may determine organ-specific growth parameters that are unaffected by removal of the fetal pituitary.
\end{abstract}

\section{Introduction}

The placental production of oestrogens, as judged by the urinary excretion of $17 \alpha$-oestradiol and oestrone in pregnant ewes (Fevre and Rombauts, 1966; Fevre, 1967) commences at about day 70 and increases rapidly between days 90 and 120 of gestation. A similar temporal pattern was observed in the oestrogen sulfoconjugates in fetal (Findlay and Cox, 1970; Findlay and Seamark, 1973) and maternal (Tsang, 1974; Carnegie and Robertson, 1978) plasma.

Kendall et al. (1977) reported that when synthetic $\mathrm{ACTH}_{1-24}$ (Synacthen: Ciba Laboratories Limited) was infused into sheep fetuses, hypophysectomized between days 110 and 120 of gestation, the preparturient oestrogen surge was not seen. They suggested that an intact fetal pituitary gland is required for the increase in the concentrations of unconjugated oestrogens in maternal plasma prepartum, although the nature of the fetal pituitary factor was unknown (except that they suggested that it did not reside in the 1-24 fraction of the ACTH molecule). In contrast, Ricketts et al. (1980) found that fetal hypophysectomy failed to block the preparturient rise in oestradiol in response to the infusion of Synacthen; however, they found that fetal hypophysectomy reduced the normal rise in oestrone sulfate, abolished the normal rise in androstenedione concentrations and reduced placental activities of C-17,20 lyase and aromatase. These fetuses were hypophysectomized between 119 and 130 days gestation.

Fetal hypophysectomy between days 110 and 124 of gestation produced no significant change in the concentrations of unconjugated oestradiol and progesterone in the plasma of ewes carrying these fetuses (Kendall et al., 1977; Robinson et al., 1977; Ricketts et al., 1980). Thus it has been concluded that the production of steroids by the ovine placenta is independent of fetal pituitary control and that placental progesterone production is autonomous. The studies on which these conclusions were based were performed after the major increase in steroid concentrations that occurs around day 90 of gestation. It therefore seemed possible that the lack of effect of fetal hypophysectomy in sheep was due to the hypophysectomy being performed too late. To test this hypothesis it was decided to hypophysectomize fetal lambs at about day 70 of gestation (term $=147$ days) before the major increase in the progesterone concentrations in maternal plasma which occurs at about 80-90 days gestation in the sheep (Bassett et al., 1969).

Our earlier data in which fetal lambs were hypophysectomized at 116 days of gestation (Mesiano et al., 1987) produced changes in the appendicular skeleton and organs shown to be pituitary dependent but other organs were affected; we therefore decided to examine the effects of a longer period of pituitary deprivation. 


\section{Materials and Methods}

\section{Animals}

Fourteen pregnant Border-Leicester $\times$ Merino ewes of known gestational age were used over the two years of this study. Trans-sphenoidal hypophysectomy was carried out aseptically on 13 fetuses (eight ewes; three singletons, five twins) between 70 and 80 days of gestation. Anaesthesia was induced with $1 \mathrm{~g}$ thiopentone sodium in water (intravenously) and was maintained after tracheal intubation with $1.5 \%$ halothane (oxygen:nitrous oxide, 50:50 vol:vol). In the case of twins, both fetuses were hypophysectomized or both were shamoperated. The fetal head was exposed through a maternal hysterotomy and held in extension with the ventral surface uppermost. The skin was incised in the midline in the area of the basihyoid bone and blunt dissection was used to approach the basisphenoid bone. This bone was then drilled through in the midline with a $3 \mathrm{~mm}$ diamond burr under $\times 10$ magnification, exposing the dura overlying the pituitary. The dura was then opened in the midline and microscopic dissection was used to free the pituitary from its coverings. The pituitary was then aspirated with a suction instrument ( 5 French gauge) and the sella turcica was packed with gelatin sponge (Gelfoam: The Upjohn Company, Kalamazoo, Michigan). The fetal skin was closed with 6-0 catgut or polypropylene suture. Sham operations were performed on ten fetuses (six ewes; two singletons, four twins) between 70 and 82 days of gestation. In this case, the soft tissue dissection was carried out to display the basisphenoid bone but no drilling was performed. All ewes were ovariectomized during surgery (to remove the ovarian component of progesterone) and vascular catheters were inserted into a maternal carotid artery, jugular vein and uterine vein.

Three of the hypophysectomized fetuses (two ewes) underwent surgery again at 116 days of gestation to insert vascular catheters into the fetal carotid artery and jugular vein. The fetal and uterine vein catheters were exteriorized via an incision in the ewe's flank. All catheters were filled with sterile heparinized saline $\left(0.9 \% \mathrm{NaCl} ; 0000 \mathrm{iu}\right.$ heparin $\left.\mathrm{l}^{-1}\right)$. After surgery, the ewes were housed in metabolic cages and fed once daily. Water was provided ad libitum. The uterine vein cannulae were thereafter continuously infused with heparinized saline using infusion pumps (Braun Perfusor Secura: B. Braun Melsungen AG, Melsungen, Germany) at a rate of $0.6 \mathrm{ml} \mathrm{h}^{-1}$.

All ewes and fetuses were killed by an overdose of barbiturate (Lethabarb: Arnolds of Reading Pty Ltd, Boronia, Victoria). Completeness of hypophysectomy was assessed by examining the sella turcica for remnants of pituitary tissue and the weights of adrenal and thyroid glands were carefully noted. The degree of wool development, a sensitive index of thyroid function (Hopkins and Thorburn, 1972), was also noted. Other fetal organs (liver, kidneys, heart, lungs and brain) were removed at autopsy and weighed.

Six ewes (eight fetuses) were killed between day 144 and day 146 of gestation. One control ewe delivered live twins before this time (143 days) and three ewes were killed at day 127 of gestation. Two of the ewes carrying hypophysectomized fetuses were allowed to continue pregnancy until day 155 of gestation before they were killed.

\section{Sample collection}

The gestational profile of the relevant hormones was examined by collecting maternal peripheral, carotid artery or jugular vein $(20-25 \mathrm{ml})$, and uterine vein $(20 \mathrm{ml})$ blood samples at 5 day intervals from 75 to 140 days of gestation, and then daily from 141 to 145 days of gestation. In most instances, peripheral samples taken were arterial, but if this catheter was blocked, jugular vein samples were collected (there was no statistical difference between sampling sites). Fetal arterial samples $(10 \mathrm{ml})$ were taken from the three re-operated fetuses between 120 and 129 days of gestation. Blood was collected between 08:00 h and 10:00 h on the day of sampling, before the ewes were fed.

Blood samples for progesterone, oestrone sulfate and placental lactogen estimation were collected into chilled tubes containing 125 iu lithium heparin (Johns Division Mallinkrodt (Australia) Pty Ltd, South Oakleigh, Victoria) and centrifuged for $10 \mathrm{~min}$ at $2000 \mathrm{~g}$ at $4^{\circ} \mathrm{C}$. The separated plasma was stored at $-20^{\circ} \mathrm{C}$.

Blood for prostaglandin $E_{2}$ measurement was collected into chilled tubes containing $15 \mathrm{mg}$ EDTA and indomethacin (final concentration $10 \mu \mathrm{moll}^{-1}$ ) and centrifuged for $10 \mathrm{~min}$ at $2000 \mathrm{~g}$ at $4^{\circ} \mathrm{C}$. The plasma was diluted $1: 1$ with 0.12 mol methoxyamine hydrochloride $\mathrm{l}^{-1}$ (Sigma Chemical Company, St Louis, MO) in sodium acetate buffer ( 1 mol $\mathrm{I}^{-1}, \mathrm{pH} \mathrm{5.6)}$ containing $10 \%$ absolute ethanol and incubated overnight at room temperature before storage at $-20^{\circ} \mathrm{C}$.

\section{Progesterone assay}

Peripheral and uterine vein plasma concentrations of progesterone were measured as described by Rice et al. (1986) with modifications. Aliquots $(50 \mu \mathrm{l})$ of plasma were extracted with $2.0 \mathrm{ml} n$-hexane (Mallinckrodt (Australia) Pty Ltd, Clayton, Victoria). Phosphate buffer (0.1 mol $1^{-1}, \mathrm{pH} \mathrm{7.0)}$ was used as diluent and $\left[1,2,6,7-{ }^{3} \mathrm{H}(N)\right]$-progesterone $\left(4218 \mathrm{GBq} \mathrm{mmol}^{-1}\right)$ was obtained from DuPont NEN Products (Boston). The antiserum ( $223 ; 1: 2500$ final dilution), raised against progesterone11- $\alpha-B S A$ in sheep, was provided by J. Malecki (Regional Veterinary Institute, Department of Agricultural and Rural Affairs, Bairnsdale, Victoria). The crossreaction of this antiserum was $100 \%$ with progesterone, $43.8 \%$ with $11 \alpha$-hydroxyprogesterone, $2.4 \%$ with pregnenolone, $<1.0 \%$ with $5 \beta$ pregnan-3 $\beta$-ol-20-one or dehydroepiandrosterone, $<0.3 \%$ with 20a-hydroxy-4-pregnen-3-one and $<2.0 \%$ with cortisol. Antibody-bound and free steroid were separated by adding $50 \mu \mathrm{l}$ normal human immunoglobulin $\left(20 \mathrm{mg} \mathrm{ml}^{-1}\right.$; Commonwealth Serum Laboratories, Melbourne) and I ml polyethylene glycol (PEG) 6000 (27\%; BDH Chemicals, Kilsyth, Victoria). The tubes were then centrifuged at $2500 \mathrm{~g}$ for $15 \mathrm{~min}$ at $4^{\circ} \mathrm{C}$. The supernatant was aspirated and the pellet dissolved in distilled $\mathrm{H}_{2} \mathrm{O}(50 \mu \mathrm{l})$. Tubes were sonicated for $30 \mathrm{~min}$ after adding $1.8 \mathrm{ml}$ scintillation fluid (ACS: Amersham Corporation, Arlington Heights, IL) and the radioactivity measured in a liquid scintillation counter (LS5000TA: Beckman Instruments Inc., Scientific Instruments Division, Fullerton, CA). The intra- and interassay coefficients of variation, estimated from 14 assays were 10.0 and $16.2 \%$, respectively. The sensitivity of the assay was $2.91 \pm 0.41 \mathrm{nmol}^{-1}$ (mean $\pm \mathrm{SEM}$ ). 


\section{Prostaglandin $E_{2}$ assay}

Peripheral and uterine vein plasma concentrations of prostaglandin $\mathrm{E}_{2}\left(\mathrm{PGE}_{2}\right)$ were measured as described by Fowden $e$ al . (1987). Labelled $\mathrm{PGE}_{2^{\prime}}\left[5,6,8,11,12,14,15{ }^{-}{ }^{3} \mathrm{H}(\mathrm{N})\right]$-prostaglandin $\mathrm{E}_{2}$ (DuPont NEN Products, Boston, MA; $6845 \mathrm{GBq} \mathrm{mmol}^{-1}$ ), and standard $\mathrm{PGE}_{2}$ (0.5 mg; Sigma, St Louis, MO) were methyl oximated as described by Fowden et al. (1987). The methyl oxime assay standards ranged from 0.02 to 1.2 pmol $\mathrm{PGE}_{2}$ per tube and plasma aliquots of 50-200 $\mu$ methyloximated samples were assayed in duplicate without extraction. Equivalent amounts of methyloximated plasma (treated with charcoal to remove steroids) were added to the standard curve. Antiserum, raised in goats against the methyl oxime of $\mathrm{PGE}_{2}$ conjugated to bovine serum albumin, was supplied by $\mathrm{R}$. F. Seamark (Adelaide). This antiserum crossreacted $100 \%$ with $\mathrm{PGE}_{2}$ methyloxime, $270 \%$ with $\mathrm{PGE}_{1}, 0.3 \%$ with $15-$ keto-PGE ${ }_{2}$ $0.1 \%$ with 13,14-dihydro-15-keto-PGF $2 \alpha$ and $<0.01 \%$ with prostaglandins $\mathrm{B}_{2^{\prime}} \mathrm{D}_{1}, \mathrm{D}_{2^{\prime}}, \mathrm{F}_{2 \alpha^{\prime}}, \mathrm{F}_{2 \beta^{\prime}}$, 6-keto-PGF $\mathrm{Pa}_{1 \alpha^{\prime}}$ thromboxane $\mathrm{B}_{2}$, 15-keto- $\mathrm{PGF}_{2 a}$ and 13,14 ,dihydro-PGF $2 \alpha$. The intra-assay coefficient of variation was $10.0 \%$ and the interassay coefficient of variation was $19.3 \%$ at $12.7 \mathrm{nmol}^{-1}$ and $17.1 \%$ at $28.0 \mathrm{nmol}^{-1}$, as estimated from 11 assays. The limit of sensitivity of the assay was $0.56 \pm 0.10 \mathrm{nmol} \mathrm{l}^{-1}$ (mean \pm SEM).

\section{Placental lactogen assay}

Peripheral plasma placental lactogen concentrations were assayed according to the method of Chan et al. (1978) as described by Rice and Thorburn (1986). Standard (prepared by the method of Chan et al., 1978) and antiserum were provided by M. J. Waters (Department of Physiology, University of Queensland, Australia). This antiserum was raised against purified ovine placental lactogen $(\mathrm{oPL})$ in goats and its crossreactivity with ovine pituitary hormones (growth hormone, luteinizing hormone, follicle-stimulating hormone, prolactin and thyroid stimulating hormone) was $<1 \%$.

\section{Oestrone sulfate assay}

Peripheral and uterine vein plasma oestrone sulfate concentrations were measured in duplicate aliquots of $20 \mu \mathrm{l}$ of plasma using an antiserum raised in sheep (6944) to oestrone-3CMO-gelatin supplied by R. I. Cox, M. S. F. Wong and R. M. Hoskinson (CSIRO Division of Animal Production, Prospect, NSW, Australia). The only steroids to crossreact significantly with this antiserum were oestrone sulfate $(100 \%)$ and oestrone (120\%). Carnegie and Robertson (1978) have shown that oestrone sulfate is the predominant oestrogen present in both fetal and maternal fluids throughout gestation in the ewe but this assay probably measures a proportion of oestrone as well as its sulfate. Aliquots $(20 \mu \mathrm{l})$ of charcoal-stripped maternal sheep plasma were added to known amounts $(0.006-1.63 \mathrm{pmol}$ per tube) of the standard oestrone sulfate (Sigma Chemical Co., St Louis, MO), before the volume in all tubes was made up to $0.1 \mathrm{ml}$ with assay buffer $\left(0.1 \mathrm{~mol}\right.$ sodium phosphate buffer $\mathrm{l}^{-1}$, $\mathrm{pH} 7.0$, containing $0.9 \%$ sodium chloride, $0.1 \%$ sodium azide and $0.1 \%$ gelatine). Standards and plasma samples were incubated at $4^{\circ} \mathrm{C}$ for a minimum of $1 \mathrm{~h}$ with $0.1 \mathrm{ml}$ tracer $\left[6,7-{ }^{3} \mathrm{H}(\mathrm{N})\right]$-oestrone sulfate, ammonium salt (DuPont NEN Products, Boston, MA; $2220 \mathrm{GBq} \mathrm{mmol}^{-1}$ ) and $0.1 \mathrm{ml}$ antiserum ( $\mathrm{T}: 39000$ final dilution) in assay buffer. Antibody-bound oestrone sulfate was precipitated with PEG 6000, as described for the progesterone radioimmunoassay. Scintillant (1.5 ml; Scintisol: Isolab, $\mathrm{OH}$ ) was added prior to counting in a liquid scintillation counter (LS5000TA; Beckman Instruments Inc., Scientific Instruments Division, Fullerton, CA). The interassay coefficient of variation was $27 \%$ at $2.49 \mathrm{nmol}^{-1}$ and $17.4 \%$ at $27.9 \mathrm{nmol} \mathrm{l}^{-1}$, estimated from 14 assays. The limit of sensitivity of the assay was 0.02 pmol per tube.

\section{Statistical analysis}

The following analyses were carried out using a program for statistical data analysis (SPSS-X). Body dimensions and organ weights were analysed by $t$ tests, using the appropriate pooled or separate variance estimate. In analysing uterine vein hormone concentrations, samples from ewes carrying singletons were from the pregnant horn only, whereas for twin pregnancies, simultaneous samples were taken from both uterine veins and concentrations were averaged for further analysis. Hormone concentrations were first tested for homogeneity of variance using Bartlett-Box $\mathrm{F}$ and Cochran's $\mathrm{C}$ test. Where hormone concentrations were found not to be homogeneous, a square root transformation was used to render these homogeneous. Concentrations were then analysed using a repeated measures analysis of variance (ANOVA), fitting polynomial functions in gestational age to the values obtained. Treatment, gestational age and individual animal were used as factors in this analysis to identify any changes in maternal hormone concentrations over the gestational period studied and any effect of fetal hypophysectomy.

\section{Results}

\section{Fetal outcome}

Fetal outcome is summarized (Table 1). Initially we had planned to re-operate on all hypophysectomized fetuses at day 116 of gestation and insert vascular catheters to collect blood samples for hormone assay and assessment of fetal well-being by measuring fetal blood gases using an ABL 30 acid base analyser and OSM2 hemoximeter (Radiometer, Copenhagen). The second operation resulted in the death of two of the three fetuses within one week and these two ewes $(1046,8086)$ were killed at 124-129 days of gestation following the rapid deterioration in the fetal blood gases. In subsequent experiments, hypophysectomized fetuses were not catheterized. The samples collected from the three catheterized fetuses were not assayed.

Owing to the difficulty in maintaining the patency of catheters and therefore the data being incomplete after 125 days of gestation, we have only included in the analysis blood samples collected from all animals between days 75 and 125 of gestation. From examination of the fetuses at autopsy, it was concluded that those fetuses that had died in utero would have been dead for only one or two days. Consequently the samples analysed to day 125 would have been unaffected. 
Table 1. Outcome of sheep fetuses undergoing early hypophysectomy

\begin{tabular}{|c|c|c|c|c|}
\hline $\begin{array}{l}\text { Ewe } \\
\text { number }\end{array}$ & $\begin{array}{l}\text { Gestational age } \\
\text { at operation } \\
\text { (days) }\end{array}$ & $\begin{array}{c}\text { Gestational age } \\
\text { at autopsy } \\
\text { (days) }\end{array}$ & $\begin{array}{l}\text { Number } \\
\text { and sex } \\
\text { of fetuses }\end{array}$ & Outcome \\
\hline \multicolumn{5}{|c|}{ Sham-operation } \\
\hline 8172 & 72 & 146 & $S, F^{c}$ & killed \\
\hline 8132 & 82 & 144 & $\begin{array}{l}\mathrm{T}, \mathrm{M}^{\mathrm{c}} \\
\mathrm{F}^{\mathrm{c}}\end{array}$ & $\begin{array}{l}\text { live birth } \\
\text { live birth }\end{array}$ \\
\hline 8205 & 71 & 145 & $\begin{array}{r}\mathrm{T}, \mathrm{F}^{\mathrm{c}} \\
\mathrm{F}^{\mathrm{c}}\end{array}$ & $\begin{array}{l}\text { killed } \\
\text { killed }\end{array}$ \\
\hline 8211 & 70 & 145 & $S, F^{c}$ & killed \\
\hline 9282 & 80 & 127 & $\begin{array}{r}\mathrm{T}, \mathrm{F} \\
?\end{array}$ & $\begin{array}{l}\text { killed } \\
\text { died in utero }\end{array}$ \\
\hline 9284 & 81 & 127 & $\begin{array}{c}\mathrm{T}, \mathrm{M} \\
\mathrm{F}\end{array}$ & $\begin{array}{l}\text { killed } \\
\text { killed }\end{array}$ \\
\hline \multicolumn{5}{|c|}{ Hypophysectomy } \\
\hline 1046 & 71 & & & \\
\hline & 116 & 124 & $S, F^{b}$ & died in utero \\
\hline 8086 & $\begin{array}{r}74 \\
116\end{array}$ & 129 & $\begin{array}{r}\mathrm{T}, \mathrm{F}^{\mathrm{b}} \\
\mathrm{F}^{\mathrm{b}}\end{array}$ & $\begin{array}{l}\text { killed } \\
\text { died in ufero }\end{array}$ \\
\hline 8140 & 73 & 144 & $\begin{array}{c}\mathrm{T}, \mathrm{M}^{\mathrm{c}} \\
?\end{array}$ & $\begin{array}{l}\text { killed } \\
\text { resorbing }\end{array}$ \\
\hline 8128 & 70 & 146 & $\mathrm{~S}, \mathrm{~F}^{\mathrm{c}}$ & killed \\
\hline 8180 & 71 & 145 & $\begin{array}{l}T, F^{c} \\
M^{c}\end{array}$ & $\begin{array}{l}\text { killed } \\
\text { killed }\end{array}$ \\
\hline 9441 & 80 & 127 & $\mathrm{~S}, ?$ & died in utero \\
\hline 9502 & 77 & 155 & $\begin{array}{r}\mathrm{T}, \mathrm{F} \\
?\end{array}$ & $\begin{array}{l}\text { died in ufero } \\
\text { resorbing }\end{array}$ \\
\hline 9503 & 79 & 155 & $\begin{array}{r}\mathrm{T}, \mathrm{M} \\
\mathrm{M}\end{array}$ & $\begin{array}{l}\text { killed } \\
\text { died in ufero }\end{array}$ \\
\hline
\end{tabular}

${ }^{2} \mathrm{~S}$ : singleton, T: twins, M: male fetus, $\mathrm{F}$ : female fetus.

'Reoperated fetuses (insertion of vascular catheters).

cFetuses included in size and weight analyses (Tables 2 and 3).

\section{Fetal body and organ weights}

The measurements taken (Tables 2 and 3) were from only those fetuses alive at the time of maternal death and between the gestational ages of 144 and 146 days. Animals outside this range were not included. Hypophysectomized fetuses appeared to have abundant subcutaneous fat, short legs relative to body length and very little wool growth at term (147 days of gestation) compared with sham-operated fetuses. Although hypophysectomized fetuses were generally smaller than shamoperated fetuses, not all body size parameters were uniformly reduced as a proportion of body length or weight (Table 3). The limbs and thyroid glands were disproportionately small, whereas the kidneys and brains were significantly heavier in the hypophysectomized group when expressed as a proportion of body weight.

\section{Hormone concentrations}

Progesterone. After day 95 of gestation, maternal peripheral progesterone concentrations increased in both treatment groups $(P<0.001)$; this increase was greater in the control group. There was no difference between the two treatment groups from day 75 to day 95 of gestation $(13.2 \pm 1.15 \mathrm{nmol}$ $1^{-1}$ ). In ewes carrying sham-operated fetuses, progesterone concentrations increased from $14.5 \mathrm{nmol} \mathrm{l}^{-1}$ at day 95 to $46.8 \mathrm{nmol}$ $1^{-1}$ at day 125 of gestation. In ewes carrying hypophysectomized fetuses, peripheral progesterone concentrations increased from $16.8 \mathrm{nmol}^{-1}$ at day 95 to $27.4 \mathrm{nmol}^{-1}$ at day 125 of gestation (Fig. 1). Progesterone concentrations in the uterine vein increased $(P<0.001)$ in both groups of ewes (hypophysectomy and control) from $51.7 \pm 11.5 \mathrm{nmol} \mathrm{l}^{-1}$ at day 75 to $121.9 \pm 15.9 \mathrm{nmol} \mathrm{l}^{-1}$ at day 125 of gestation; there was no difference between the two treatment groups.

Prostaglandin $E_{2} . \quad \mathrm{PGE}_{2}$ concentrations were not different between the two treatment groups from day 75 to day 95 of gestation in either peripheral $\left(1.90 \pm 0.23 \mathrm{nmol} \mathrm{l}^{-1}\right)$ or uterine vein plasma $\left(1.90 \pm 0.32 \mathrm{nmol} \mathrm{l}^{-1}\right)$. Peripheral plasma $\mathrm{PGE}_{2}$ concentrations in control ewes increased $(P<0.001)$ after day 95 to exceed $11.7 \mathrm{nmol} \mathrm{l}^{-1}$ by day 125 of gestation, whereas concentrations in ewes carrying hypophysectomized fetuses did not change, but remained at about $1.59 \pm 0.16 \mathrm{nmol} \mathrm{l}^{-1}$, throughout the gestational period studied (Fig. 2). Uterine vein plasma $\mathrm{PGE}_{2}$ concentrations also increased $(P<0.001)$ in control ewes after day 95 to exceed $13.5 \mathrm{nmol}^{-1}$ by day 125 . 
Table 2. Size and dimensions of sheep fetuses undergoing early hypophysectomy and surviving to term (147 days) and weight of fetal organs

\begin{tabular}{|c|c|c|c|}
\hline & $\begin{array}{l}\text { Hypophysectomy } \\
\qquad(n=4)\end{array}$ & $\begin{array}{l}\text { Sham } \\
(n=6)\end{array}$ & \\
\hline & \multicolumn{2}{|c|}{ Mean ( \pm SEM) length of part $(\mathrm{cm})$} & $\begin{array}{l}\text { Hypophysectomy } \\
\text { as \% of control }\end{array}$ \\
\hline Crown-anus & $42.3 \pm 0.63$ & $46.2 \pm 1.39$ & 92 \\
\hline Head & $12.4 \pm 0.13^{\mathrm{a}}$ & $13.3 \pm 0.25^{\mathrm{b}}$ & 93 \\
\hline Forelimb & $31.0 \pm 0.58^{\mathrm{c}}$ & $41.9 \pm 1.18^{\mathrm{d}}$ & 74 \\
\hline \multirow[t]{2}{*}{ Hindlimb } & $36.8 \pm 0.63^{c}$ & $45.9 \pm 0.80^{\mathrm{d}}$ & 80 \\
\hline & \multicolumn{2}{|c|}{ Mean ( \pm SEM) weight of part $(g)$} & $\begin{array}{l}\text { Hypophysectomy } \\
\text { as } \% \text { of control }\end{array}$ \\
\hline Fetus $(\mathrm{kg})$ & $3.24 \pm 0.08^{\mathrm{a}}$ & $4.39 \pm 0.42^{b}$ & 74 \\
\hline Liver & $95.1 \pm 12.0$ & $92.8 \pm 13.3$ & 102 \\
\hline Kidneys & $19.0 \pm 0.56$ & $21.8 \pm 2.35$ & 87 \\
\hline Adrenal glands & $0.23 \pm 0.02^{c}$ & $0.47 \pm 0.02^{\mathrm{d}}$ & 49 \\
\hline Heart & $19.1 \pm 1.46^{\mathrm{a}}$ & $33.1 \pm 3.58^{\mathrm{b}}$ & 58 \\
\hline Lungs & $67.6 \pm 9.63^{\mathrm{a}}$ & $113.2 \pm 12.4^{\mathrm{b}}$ & 60 \\
\hline Thyroid & $0.24 \pm 0.02^{\mathrm{c}}$ & $0.97 \pm 0.12^{\mathrm{d}}$ & 25 \\
\hline Brain & $56.8 \pm 1.41$ & $56.9 \pm 2.24$ & 100 \\
\hline
\end{tabular}

"Values are statistically different from ${ }^{b}$ values $(P<0.05)$

'Values are statistically different from ${ }^{\mathrm{d}}$ values $(P<0.005)$.

Table 3. Dimensions of sheep fetuses undergoing early hypophysectomy and surviving to term (147 days), expressed as a percentage of crown-anus length and organ weights expressed as a percentage of fetal body weight

\begin{tabular}{lcc}
\hline & $\begin{array}{c}\text { Hypophysectomy } \\
(n=4)\end{array}$ & $\begin{array}{c}\text { Sham } \\
(n=6)\end{array}$ \\
\hline Length & Mean $( \pm$ SEM $) \%$ of crown-anus length \\
Head & $29.4 \pm 0.37$ & $28.9 \pm 0.55$ \\
Forelimb & $73.4 \pm 1.86^{\mathrm{e}}$ & $90.9 \pm 1.48^{\mathrm{f}}$ \\
Hindlimb & $87.0 \pm 1.43^{\mathrm{c}}$ & $99.7 \pm 1.66^{\mathrm{d}}$ \\
Weight & Mean $( \pm$ SEM $) \%$ of body weight \\
Liver & $3.02 \pm 0.46$ & $2.09 \pm 0.17$ \\
Kidneys & $0.06 \pm 0.004^{\mathrm{a}}$ & $0.05 \pm 0.003^{\mathrm{b}}$ \\
Adrenal glands & $0.0008 \pm 0.0$ & $0.0011 \pm 0.0$ \\
Heart & $0.06 \pm 0.006$ & $0.075 \pm 0.004$ \\
Lungs & $2.15 \pm 0.35$ & $2.62 \pm 0.27$ \\
Thyroid & $0.0008 \pm 0.0^{\mathrm{c}}$ & $0.002 \pm 0.0^{\mathrm{d}}$ \\
Brain & $1.79 \pm 0.09^{\mathrm{a}}$ & $1.35 \pm 0.10^{\mathrm{b}}$ \\
& & \\
\hline
\end{tabular}

${ }^{2}$ Values are statistically different from ${ }^{b}$ values $(P<0.05)$

${ }^{c}$ Values are statistically different from ${ }^{d}$ values $(P<0.005)$.

eValues are statistically different from 'values $(P<0.001)$.

Concentrations in ewes carrying hypophysectomized fetuses increased after day 105 to reach $8.63 \mathrm{nmol} \mathrm{l}^{-1}$ by day 125 of gestation. This increase has occurred approximately 10 days after that for control ewes.

Oestrone sulfate. In control ewes, peripheral oestrone sulfate concentrations increased progressively $(P<0.001)$ from

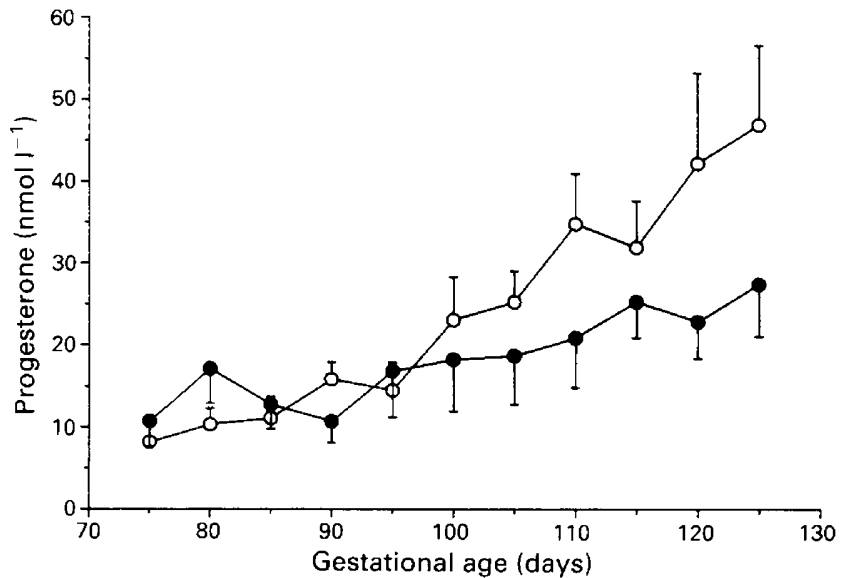

Fig. 1. Progesterone concentrations in peripheral plasma from ewes carrying hypophysectomized fetuses $(0, n=8)$ and ewes carrying sham-operated fetuses $(O, n=6)$, expressed as means \pm SEM.

$0.08 \mathrm{nmol} \mathrm{l}^{-1}$ at day 80 to exceed $4.30 \mathrm{nmol}^{-1}$ at day 125 of gestation (Fig. 3). Uterine vein oestrone sulfate concentrations in control ewes also increased $(P<0.001)$ from $0.91 \mathrm{nmol}^{-1}$ at day 80 to $6.95 \mathrm{nmol} \mathrm{I}^{-1}$ at day 125 of gestation. In ewes carrying hypophysectomized fetuses, oestrone sulfate concentrations did not change from day 80 to day 125 of gestation in either peripheral (remaining at $1.98 \pm 0.17 \mathrm{nmol}^{-1}$ ) or uterine vein plasma (remaining at $1.50 \pm 0.19 \mathrm{nmol} \mathrm{l}^{-1}$ ).

Placental lactogen. Placental lactogen was measured only in blood sampled from maternal peripheral catheters. Concentrations increased in all ewes $(P<0.001)$ from 


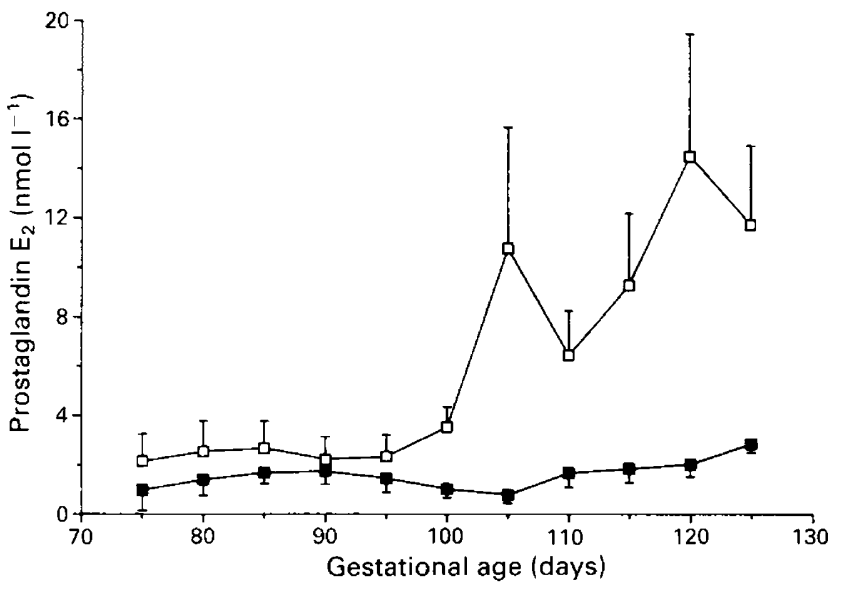

Fig. 2. Prostaglandin $E_{2}$ concentrations in peripheral plasma from ewes carrying hypophysectomized fetuses $(\square, n=8)$ and ewes carrying sham-operated fetuses $(\square, n=6)$, expressed as means \pm SEM.

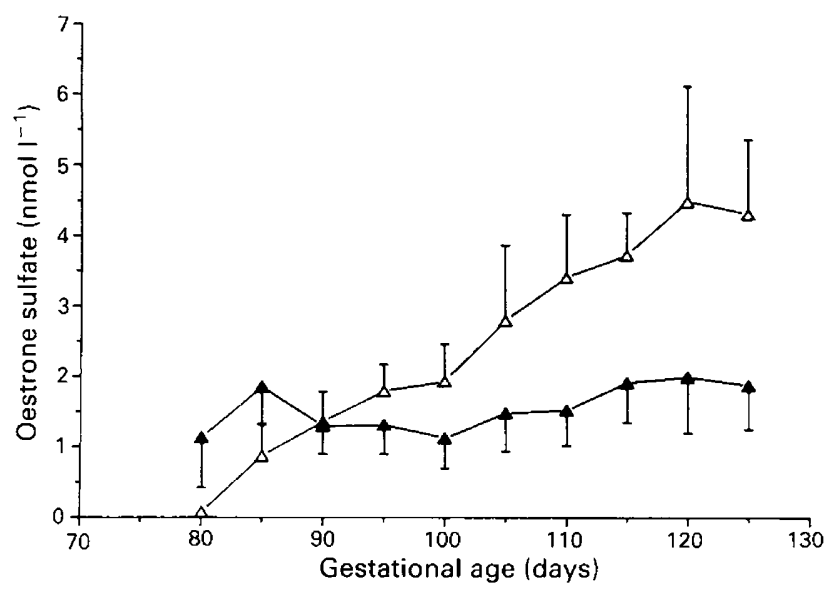

Fig. 3. Oestrone sulfate concentrations in peripheral plasma from ewes carrying hypophysectomized fetuses $(\boldsymbol{\Lambda}, n=8)$ and ewes carrying sham-operated fetuses $(\triangle, n=6)$, expressed as means \pm SEM.

$7.18 \pm 4.16 \mathrm{nmol} \mathrm{l}^{-1}$ at day 75 to $49.6 \pm 9.51 \mathrm{nmol} \mathrm{l}^{-1}$ at day 125 of gestation.

\section{Discussion}

Fetal hypophysectomy at days 70-80 of gestation decreased maternal plasma concentrations of progesterone between day 95 and day 125 compared with sham-operated controls, but progesterone concentrations increased in both groups after day 95 of gestation. This suggests that the fetal pituitary does have some influence on placental progesterone production. The nature of the pituitary trophic factor is unknown.

This study has confirmed earlier observations of a parallel increase in the maternal plasma concentrations of progesterone and ovine placental lactogen (oPL) (Chan et al., 1978; Taylor et al., 1983). The reason for this association is unknown. Studies with human trophoblast explants (Handwerger et al., 1987) and cells (Sane et al., 1988) showed that high density lipoproteins (HDL) stimulated the release of human placental lactogen and that the active components were the apoproteins of HDL. Recently Grandis et al. (1989) have also shown in sheep that ovine HDL, but not lipoprotein-free plasma proteins, stimulate the secretion of oPL in pregnant ewes. Liggins and Thorburn (in press) have proposed that the uptake of HDL by the ovine placenta provides cholesterol for progesterone synthesis, arachidonic acid as a precursor for $\mathrm{PGE}_{2}$ synthesis and provides a stimulus for oPL release. Thus the uptake of HDL by the ovine placenta between 90 and 125 days of gestation may explain the parallel increase in the plasma concentrations of progesterone, $\mathrm{PGE}_{2}$ and oPL.

In contrast to the findings with progesterone, fetal hypophysectomy abolished the increase in maternal plasma concentrations of oestrone sulfate between days 90 and 125 of gestation. The source of the precursors for placental oestrogen biosynthesis is a matter of debate. It is possible that the fetal adrenal gland secretes C-19 steroids which are readily converted by placental aromatase to oestrogens. Mitchell et al. (1986) showed that $30 \%$ of maternal oestrogen is derived from androstenedione of fetal origin. Fetal hypophysectomy, by removing pituitary $\mathrm{ACTH}$, would inhibit the secretion of $\mathrm{C}-19$ steroids by the fetal adrenal gland and could explain the failure of placental oestrogen synthesis to increase in these experiments. Alternatively, despite extremely low concentrations of $17 \alpha$-hydroxylase in the placenta at that time (France et al., 1988; Mason et al., 1989), the activity of this enzyme may be sufficient to metabolize small amounts of pregnenolone through the $\Delta 5$-pathway to oestrogens.

Fetal hypophysectomy also abolished the expected increase in placental $\mathrm{PGE}_{2}$ production during the last third of gestation; however, the concentration of prostaglandin in the uterine vein did increase from 110 days onwards. This discrepancy may be explained in part by a fall in uterine blood flow following fetal hypophysectomy. Earlier studies by our group have shown that the progressive increase in matemal arterial and uterine vein $\mathrm{PGE}_{2}$ concentrations (Fowden et al, 1987) parallel the increase in prostaglandin $\mathrm{H}$ synthase (PGHS) activity in the ovine placenta (Risbridger et al., 1985; Rice et al., 1988, 1990). Rice et al. (1990) have shown that fetal hypophysectomy inhibits this increase in placental PGHS activity, which suggests that the increase in $\mathrm{PGE}_{2}$ production by the ovine placenta is secondary to the increase in PGHS activity and that it is under the influence of the fetal pituitary. The immunohistochemical studies of Boshier et al. (1991) indicate that during the last 30 days of gestation, PGHS is situated mainly in the fetal trophoblast and that PGHS is not present in the binucleate cells, which are thought to form part of the maternal syncytium (Wooding, 1984). Ralph (1991), using cell cultures, has shown that the uninucleate cells of the trophoblast and the fibroblasts of the ovine placentome produce prostaglandins. Risbridger et al. (1985) had earlier shown that placental (trophoblast) cells were the major site of prostaglandins during this time. These studies suggest that fetal pituitary hormones may regulate placental PGHS either directly or indirectly. It has been shown in the rat ovary (Clark et al., 1979) that LH can induce PGHS activity. LH from the fetal pituitary may therefore play a role in regulating 
placental PGHS (Thorburn et al., 1989) and the results reported here are consistent with this view.

The present study extends our knowledge of the effects of hypophysectomy on growth of the fetus. We have previously reported the effects of hypophysectomy carried out at about 115 days, noting that the organs that are most severely growth retarded were the appendicular skeleton and adrenal glands (Mesiano et al., 1987). The effects of a longer period of fetal pituitary deprivation reported here confirm our earlier data and extend the findings of earlier studies (Liggins and Kennedy, 1968; Parkes and Hill, 1985). In addition, early hypophysectomy (days 70-80 of gestation) results in significant deficits in fetal head length, body weight, and heart, lung and thyroid weights which were not affected by hypophysectomy later in gestation. However, in the previous study (Mesiano et al., 1987) insufficient time may have elapsed between hypophysectomy and autopsy for these effects to attain statistical significance.

Examination of the standardized weights and dimensions (Table 3 ) reveals that the pattern of growth associated with early fetal hypophysectomy is similar to that of control fetuses except that the limbs are disproportionately short, thyroid weight is disproportionately reduced and brain, liver and kidney weights are relatively spared. These findings suggest that the growth of the brain, liver and kidney is regulated differently from that of most other organs. Indeed, the weights of the brain, liver and kidney of hypophysectomized fetuses at autopsy were the same as those of the controls. These results suggest that these organs grow in response to an extra-pituitary stimulus that may be independent of fetal pituitary control and could be oPL. Similarly, the increase in subcutaneous adipose tissue following hypophysectomy may result from removal of the lipolytic action of pituitary hormones (e.g. growth hormone) while the lipogenic action of oPL is maintained. If so, oPL receptors should be present in these tissues. In contrast, the weights of the heart and lungs were reduced in proportion to body weight, suggesting that the heart, lungs and carcass were under the control of the fetal pituitary. To our knowledge, this is the first report that the growth of the fetal heart and lungs may be under the influence of pituitary hormones, but the relative importance of the individual pituitary hormones and locally produced growth factors are not addressed by this study.

After hypophysectomy, the fetal limbs continue to grow. If the growth of the limbs between the time of surgery and autopsy (obtained by subtracting the values estimated from Cloete's (1939) growth data, i.e. forelimb length $9.0 \mathrm{~cm}$, hindlimb length $10.0 \mathrm{~cm}$ from the observed values for hypophysectomized and sham-operated fetuses) is considered, then it appears that the limbs of hypophysectomized fetuses elongated by about $70 \%$ of the values obtained for the sham-operated controls. Interestingly, application of this method to the data generated by hypophysectomy later in gestation yields a similar estimate of the proportion of limb growth that is pituitary dependent. This suggests that the mechanisms governing limb growth do not alter markedly after mid-gestation.

The relative contributions of the various pituitary hormones to somatic growth remain unclear. The present findings of reduced body weight, limb length and skin development are consistent with fetal hypothyroidism (Hopkins and Thorburn, 1972), although we were unable to ameliorate these deficiencies by thyroxine replacement in our previous study (Mesiano et al.,
1987). Although the hypophysectomized ovine fetus is practically athyroid (Thorburn and Hopkins, 1973), the present study failed to reproduce the retardation of brain growth noted by Bhakthavathsalan et al. (1977) after fetal thyroidectomy carried out at 104-111 days of gestation.

In conclusion, our results suggest that the fetal pituitary influences growth, placental steroidogenesis and prostaglandin production after day 90 of gestation in sheep. Further studies are required to determine which pituitary factors are involved.

This research was supported by the National Health and Medical Research Council of Australia. The authors wish to thank M. Ralph for advice and support, V. Ford for expert technical assistance, J. Norman and A. Satragno for surgical assistance and D. Caddy for his statistical advice.

\section{References}

Bassett JM, Oxborrow TJ, Smith ID and Thorburn GD (1969) The concentration of progesterone in the peripheral plasma of the pregnant ewe Joumal of Endocrinology 45 449-457

Bhakthavathsalan A, Mann LI, Ayromlooi J, Kunzel W and Liu M (1977) The effects of fetal thyroidectomy in the ovine fetus American Joumal of Obstetrics and Gynecology 127 278-284

Boshier DP, Jacobs RA, Han VKM, Smith W, Riley SC and Challis JRG (1991) Immunohistochemical localization of prostaglandin $\mathrm{H}_{2}$-synthase in the sheep placenta from early pregnancy to term Biology of Reproduction 45 322-327

Carnegie JA and Robertson HA (1978) Conjugated and unconjugated oestrogens in fetal and maternal fluids of the pregnant ewe: a possible role for estrone sulfate during early pregnancy Biology of Reproduction 19 202-211

Chan JSD, Robertson HA and Friesen HG (1978) Maternal and fetal concentrations of ovine placental lactogen measured by radioimmunoassay Endocrinology 102 1606-1613

Clark MR, Chauny GBN, Marsh JM and LeMaire WJ (1979) Stimulation of prostaglandin synthetase activity in rat granulosa cells by gonadotropins in vivo Prostaglandins 17 967-974

Cloete JHL (1939) Prenatal growth in the merino sheep Onderstepoort Journal of Veterinary Science and Animal Industry 13 417-558

Fevre J (1967) Urinary oestrogens in the ovariectomized pregnant ewe Annales de Biologie animale Biochimie, Biophysique $729-32$

Fevre J and Rombauts P (1966) Étude de l'excretion urinaire des oestrogenes chez la Brebis pendant la gestation Annales de Biologie animale Biochimie Biophysique 6 165-177

Findlay JK and Cox RI (1970) Oestrogens in the plasma of the sheep foetus Joumal of Endocrinology 46 281-282

Findlay JK and Seamark RF (1973) The occurrence and metabolism of oestrogens in the sheep foetus and placenta. In The Endocrinology of Pregnancy and Parturition pp 54-70 Ed. CG Pierrepoint. Alpha Omega Alpha Publishing, Cardiff

Fowden AL, Harding R, Ralpha MM and Thorburn GD (1987) The nutritional regulation of plasma prostaglandin $\mathrm{E}$ concentrations in the fetus and pregnant ewe during late gestation Journal of Physiology 394 1-12

France JT, Magness RR, Murry BA, Rosenfeld CR and Mason JI (1988) The regulation of ovine placental steroid 17 alpha-hydroxylase and aromatase by glucocorticoid Molecular Endocrinology 2 193-199

Grandis A, Jorgensen V, Kodack L, Quarfordt S and Handwerger S (1989) Highdensity lipoproteins (HDL) stimulate placental lactogen secretion in pregnant ewes: further evidence for a role of HDL in placental lactogen secretion during pregnancy Joumal of Endocrinology 120 423-427

Handwerger S, Quarfordt S, Barrett J and Harman I (1987) Apolipoproteins AI, AII and $\mathrm{CI}$ stimulate placental lactogen release from human placental tissue. A novel action of high density lipoprotein apolipoproteins Journal of Clinical Investigation $79625-628$

Hopkins PS and Thorburn GD (1972) The effects of foetal thyroidectomy on the development of the ovine foetus Joumal of Endocrinology 54 55-66

Kendall JZ, Challis JRG, Hart IC, Jones CT, Mitchell MD, Ritchie JWK, Robinson JS and Thorburn GD (1977) Steroid and prostaglandin concentrations in the plasma of pregnant ewes during infusion of adrenocortico- 
trophin or dexamethasone to intact or hypophysectomized fetuses Journal of Endocrinology 75 59-71

Liggins GC and Kennedy PC (1968) Effects of electrocoagulation of the foetal lamb hypophysis on growth and development Joumal of Endocrinology $\mathbf{4 0}$ 371-381

Liggins GC and Thorburn GD The Initiation of Parturition. In Marshall's Physiology of Reproduction Vol 3 (4th Edn) Ed. GE Lamming. Chapman and Hall, London (in press)

Mason JI, France JT, Magness RR, Murry BA and Rosenfeld CR (1989) Ovine placental steroid $17 \alpha$-hydroxylase/C-17,20-lyase, aromatase and sulphatase in dexamethasone-induced and natural parturition Journal of Endocrinology $122351-359$

Mesiano S, Young IR, Baxter RC, Hintz RL, Browne CA and Thorburn GD (1987) Effect of hypophysectomy with and without thyroxine replacement on growth and circulating concentrations of IGF-I and II in the fetal lamb Endocrinology 120 1821-1830

Mitchell BF, Lye SJ, Lukash L and Challis JRG (1986) Androstenedione metabolism in the late gestation sheep fetus Endocrinology 118 63-68

Parkes MJ and Hill DJ (1985) Lack of growth hormone dependent somatomedins or growth retardation in hypophysectomised fetal lambs Journal of Endocrinology 4 193-199

Ralph MM (1991) Is the secretion of prostaglandins from ovine uninucleate trophoblast directional? Australian Society for Reproductive Biology 23106

Rice GE and Thorburn GD (1986) Stimulation of ovine choriomammotrophin release, in vitro, by phospholipase C Placenta 7 533-542

Rice GE, Jenkin G and Thorburn GD (1986) Comparison of particle-associated progesterone and oxytocin in the ovine corpus luteum Joumal of Endocrinology $108109-116$

Rice GE, Wong MH and Thorburn GD (1988) Gestational changes in prostaglandin synthase activity of ovine cotyledonary microsomes Journal of Endocrinology 118 265-270
Rice GE, Wong MH, Hollingworth S and Thorburn GD (1990) Prostaglandin $\mathrm{G} / \mathrm{H}$ synthase activity in ovine cotyledons: a gestational profile Eicosanoids 3 231-236

Ricketts AP, Sheldrick EL, Lindsay KS and Flint APF (1980) Induction of labour in sheep after fetal hypophysectomy: an investigation of the possible involvement of a fetal pituitary secretion in the activation of placental enzymes by fetal cortisol Placenta 1 287-297

Risbridger GP, Leach-Harper CM, Wong MH and Thorburn GD (1985) Gestational changes in prostaglandin production by ovine fetal trophoblast cells Placenta 6 117-126

Robinson JS, Challis JRG, Pooley G and Thorburn GD (1977) Foetal and matemal cortisol and progesterone and maternal oestradiol in prolonged pregnancy after foetal hypophysectomy in sheep Journal of Endocrinology $\mathbf{7 2}$ 241-242

Sane A, Harman I, Quarfordt S, Costello A and Handwerger S (1988) Characterisation of placental lactogen release from perifused human trophoblast cells Placenta 9 129-138

Taylor MJ, McMillen IC, Jenkin G, Robinson JS and Thorburn GD (1983) The regulation of ovine placental lactogen: the role of the fetal hypothalamicpituitary axis Joumal of Developmental Physiology 5 251-258

Thorburn GD and Hopkins PS (1973) Thyroid function in the foetal lamb. In Foetal and Neonatal Physiology, Sir Joseph Barcroft Centenary Symposium pp 488-507 Eds RS Comline, K Cross, GS Dawes and PW Nathanielsz. Cambridge University Press, Cambridge

Thorburn GD, Deayton JM, Young IR and Ralph MM (1989) The effects of early fetal hypophysectomy on ovine placental $\mathrm{PGE}_{2}$ and steroid biosynthesis Joumal of Reproduction and Fertility Abstract Series 3 Abstract 49

Tsang C (1974) Changes in plasma levels of oestrone sulphate and oestrone in the pregnant ewe around parturition Steroids 23 855-868

Wooding FBP (1984) Role of binucleate cells in fetomaternal cell fusion at implantation in the sheep American Joumal of Anatomy 170 233-250 